\title{
Sugar content variability in simple sterile hybrids as components of experimental hybrids as affected by genotype and environment
}

\author{
Kornieieva M. 0.", Nenka M. M. \\ Institute of Bioenergy Crops and Sugar Beet of NAAS, 25 Klinichna Str., Kyiv, 03141, Ukraine
}

\author{
Received 4 Sep 2015 \\ Accepted 15 Now 2015 \\ *Correspondence: \\ e-mail: mira31@ukr.net
}

\begin{abstract}
Keywords:
CMS (cytoplasmic male sterile) line, sterility maintainer, simple sterile hybrids, sugar content, combining ability
\end{abstract}

Purpose. To identify genetic determination and phenotypic expression of sugar content characteristic in simple sterile hybrids as parent components of experimental combinations as affected by nutrition background and growing space. To select the best ones in terms of their adaptive ability to abiotic environmental factors in multifactor experiment. Methods. Variety test of simple sterile hybrids, sterility maintainers and their simple sterile analogues in various environments as follows: normal fertilization background, normal growing space (NBNGS); normal background, extended growing space (NBEGS); enhanced fertilization background, normal growing space (EBNGS); enhanced background, extended growing space (EBEGS). Results. Differentiation capacity of NBEGS environment was higher than NBNGS (5 and 7 best hybrids were selected, respectively). Against the enhanced background, extended growing space also was the best for the selection of genetic lines for their sugar content characteristic. In EBEGS selected were 8 hybrids that greatly exceed average population value, whereas in EGNGS only 5. Proportion of non-additively genes action in EGS was also higher compared to NGS (50 vs. 40\%). Conclusion. Established was variability of phenotypic manifestation of sugar content against the different fertilization backgrounds and growing space. The best hybrids featured stable effect on the sugar content against both backgrounds were CMS 1/Ot 2, CMS 2/Ot 1, CMS 5/Ot 1 and CMS 2/Ot 5, as evidenced by the cumulative effect of GCA and SCA. SCA was more variable in relation to the area of supply than GCA. CMC 1 and CMC 5 lines were distinguished as carriers of additive genes controlling sugar content and were characterized by stable phenotypic expression.

\section{Introduction}

Sugar content is an important element of sugar beet productivity that makes a breeding goal in the development of hybrids based on CMS (cytoplasmic male sterility). Many scientists pointed out that sugar content is characterized by a significant variation factor (from 15 to 21\%) which was significantly lower compared to yield [1,2]. Studying the variability of populations of different origins, it was found that the populations of the same variability were characterized by different absolute values of the sugar content, and vice versa [3]. Some scientists pointed at the appearance of transgress forms in the offspring with the frequency $0.7-1.4 \%$ [4].

Variability of sugar content depends either on the genotypic factors or conditions of the environment and their interaction. The variability of this feature in populations depends mainly on the additive gene effects; in interline hybrids it depends on the additive and non-additive effects [5-7]. However, the phenotypic expression of sugar content is influenced significantly by other factors (environmental, agronomic, and others) that "mask" genetic parameters contributing to this feature, and create difficulties in the selection of genotypes.

"Cell method" (hexagonal method of organizing plants) with the intensity of selection of $15 \%$ was used to equalize differences caused by the environment in breeding of some crops. Many authors indicated modifications in the growing space of sugar beet. Thus, A. L. Mazlumov considered that the use of the extended growing space could identify all capabilities of the genotypes ensured by the nature [8]. He wrote that the extended growing space influenced the variability of useful traits of beets more than special properties of soil or fertilizers. According to other researchers, it was shown that sugar content was higher in the progeny selected against the extended growing space than against 
normal growing space. Moreover, the expansion of the phenotypic variance into genotypic and environmental components showed that the proportion of the genotypic variance in the total phenotypic structure was higher against the extended growing space [9].

\section{Purpose}

To identify genetic determination and phenotypic expression of sugar content characteristic in simple sterile hybrids as parent components of experimental combinations as affected by nutrition background and growing space. To select the best ones in terms of their adaptive ability to abiotic environmental factors in multifactor experiment.

\section{Materials and Methods}

Female parent component was represented by two 0-types: simple sterile hybrids (SSH) derived from crosses of sterile (CMS) lines with unrelated sterility maintainers (SM) and CMS line-analogues of 0-type. The experiment was carried at the Institute of Bioenergy Crops and Sugar Beet (IBCSB) in 2011-2013 in different environments. The backgrounds were as follows: normal fertilization background, normal growing space (NBNGS); normal background, extended growing space (NBEGS); enhanced fertilization background, normal growing space (EBNGS); enhanced background - extended growing space (EBEGS).

\section{Results and Discussion}

Sugar content of simple sterile hybrids (SSH) in the environments NBNGS and NBEGS

As the analysis of sugar content showed (Table 1), SSH was characterized by specific reaction to changes in the area of supply in the environments NBNGS and NBEGS.

Table 1

Sugar content of SSH, deviation from average and standard environments of NBNGS and NBEGS

(IBCSB of NAAS, 2011-2013)

\begin{tabular}{|c|c|c|c|c|c|c|}
\hline \multirow{3}{*}{$\begin{array}{l}\text { Simple sterile } \\
\text { hybrids }\end{array}$} & \multicolumn{6}{|c|}{ Growing space } \\
\hline & \multicolumn{3}{|c|}{ NBNGS } & \multicolumn{3}{|c|}{ NBEGS } \\
\hline & $\begin{array}{c}\text { Sugar } \\
\text { content, \% }\end{array}$ & $\begin{array}{l}\text { Deviation from } \\
\text { the average, } \%\end{array}$ & $\begin{array}{l}\text { Deviation } \\
\text { from } \mathrm{St}, \%\end{array}$ & $\begin{array}{c}\text { Sugar } \\
\text { content, \% }\end{array}$ & $\begin{array}{l}\text { Deviation from } \\
\text { the average, \% }\end{array}$ & $\begin{array}{r}\text { Deviation } \\
\text { from St, \% }\end{array}$ \\
\hline CMS 1/Ot 2 & 16.5 & $-0.5^{*}$ & -4.3 & 17.8 & $0.8^{*}$ & 3.3 \\
\hline CMS 1/Ot 3 & 16.7 & -0.3 & -3.3 & 16.0 & $-0.9 *$ & -7.2 \\
\hline CMS 1/Ot 4 & 16.6 & $-0.4^{*}$ & -3.9 & 17.2 & 0.2 & -0.2 \\
\hline CMS 1/Ot 5 & 16.5 & $-0.4^{*}$ & -4.1 & 18.1 & $1.1^{*}$ & 4.8 \\
\hline CMS 2/Ot 1 & 17.3 & $-0.4^{*}$ & 0.5 & 17.2 & 0.2 & -0.2 \\
\hline CMS 2/Ot 3 & 16.9 & -0.1 & -2.2 & 15.9 & $-1.1^{*}$ & -7.7 \\
\hline CMS 2/Ot 4 & 17.1 & 0.1 & -0.8 & 16.2 & $-0.8^{*}$ & -6.2 \\
\hline CMS 2/Ot 5 & 17.6 & $0.6^{*}$ & 1.4 & 17.5 & $0.6^{*}$ & 1.7 \\
\hline CMS 3/Ot 1 & 17.3 & $0.4^{*}$ & 0.5 & 17.8 & $0.8^{*}$ & 3.3 \\
\hline CMS 3/Ot 2 & 16.5 & $-0.5^{*}$ & -4.5 & 16.3 & $-0.6^{*}$ & -5.2 \\
\hline CMS 3/Ot 4 & 17.3 & $0.4^{*}$ & 0.5 & 16.9 & -0.1 & -2.1 \\
\hline CMS 3/Ot 5 & 17.8 & $0.8^{*}$ & 3.0 & 17.2 & 0.2 & -0.2 \\
\hline CMS 4/Ot 1 & 16.9 & -0.1 & -1.8 & 17.4 & $0.4^{*}$ & 0.8 \\
\hline CMS 4/Ot 2 & 16.6 & $-0.4^{*}$ & -3.9 & 16.5 & $-0.5^{*}$ & -4.3 \\
\hline CMS 4/Ot 3 & 16.6 & $-0.4^{*}$ & -3.7 & 16.2 & $-0.8^{*}$ & -5.8 \\
\hline CMS 4/Ot 5 & 17.5 & $0.5^{*}$ & 1.3 & 17.2 & 0.2 & -0.2 \\
\hline CMS 5/Ot 1 & 17.1 & 0.2 & -0.6 & 16.7 & -0.3 & -3.1 \\
\hline CMS 5/Ot 2 & 16.4 & $0.6^{*}$ & -5.1 & 17.7 & $0.7^{*}$ & 2.5 \\
\hline CMS 5/Ot 3 & 17.1 & 0.2 & -0.6 & 17.4 & $0.4^{*}$ & 1.0 \\
\hline CMS 5/Ot 4 & 16.9 & -0.1 & -2.0 & 16.2 & $-0.7^{*}$ & -5.8 \\
\hline
\end{tabular}

$* \mathrm{LSD}_{0.5}$

As data of Table 1 show, NBNGS showed significant positive deviation from the average value in five $\mathrm{SSH}$, whereas NBEGS in seven, i.e. extended growing space (EGS) promoted increased sugar content. There is a specific reaction of genotypes: some hybrids reduced the feature value on the EGS (CMS 1/Ot 3, CMS 2/Ot 3, CMS 2/Ot 4, CMS 3/Ot 4, CMS 3/Ot 5, and CMS 5/Ot 1) while other were not sensitive to this factor. Some of them (CMS 5/Ot 2, CMS 1/Ot 2, CMS 1/Ot 4, CMS 1/Ot 5, CMS 4/Ot 1, 
and CMS 5/Ot 2) increased sugar content. It is in a good agreement with the observations by A. L. Mazlumov [8], who wrote that the sugar content on different GS varied in a different way. There are plants in which the sugar content does not change, or increases. Selection of lines with high sugar content against this background improved the material on this feature significantly.

EGS contributed to the manifestation of high sugar content in the hybrid CMS 1/0t 5, which showed the highest value of the index (18.1\%). The similar tendency was observed in the combinations with high sugar content CMS 3/Ot 1 (17.8\%) and CMS 5/Ot 2 (17.7\%), which did not show themselves in the control variant NBNGS. The best hybrids CMS 1/Ot 2, CMS 1/Ot 4, CMS 3/Ot 1 and CMS 5/Ot 2 increased the group standard by $2.5 . . .4 .8 \%$ in terms of sugar content.

The range of variation in the sugar content on EGS was higher than on NGS. The amplitude values of this index varied from 15.9...18.1\% (EGS) and 16.4...17.6\% (NGS), with the difference of 2.2 and 1.2\% respectively.

Phenotypic variability of sugar content in hybrids was divided into genotypic and environmental components by means of dispersion analysis. It turned out that the effect of the genotype in the variation NBEGS was larger than in NBNGS (86.6 vs. 69.2\%, respectively). It indicated a good differentiating ability of such factors as the EGS for the manifestation of the genotype. Genotypic variance was also divided into components (Fig. 1,2).

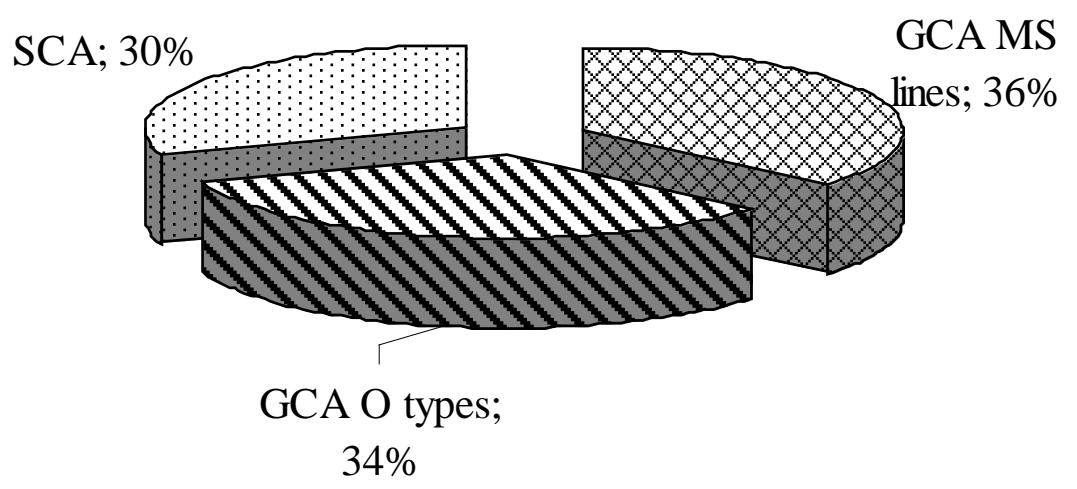

Fig. 1 Genotypic variability and its share in sugar content characteristic of simple sterile hybrids, 2011-2013, NBNGS

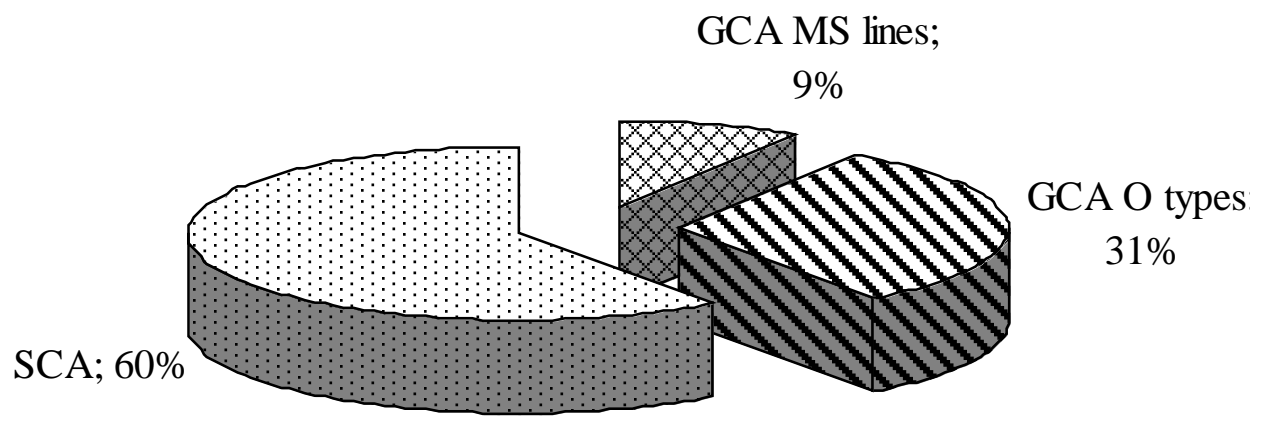

Fig. 2 Genotypic variability and its share in sugar content characteristic in simple sterile hybrids, 2011-2013, NBEGS

Noteworthy is that the additive effects of genes of both parent forms (SCA of CMS lines + SCA O-types) on the EGS was lower than in NGS and made the total of $40 \mathrm{vs.} 70 \%$, meanwhile the share of non-additive actions of gene was higher ( $60 \mathrm{vs.} 30 \%$ ). It shows that effects of components interaction became more significant in EGS (Fig. 1,2).

Significant influence of parent forms and their interactions in NBNGS revealed the effects of the combining ability: general (GCA) and specific (SCA) (Table 2). 
The effects of GCS and SCA of CMS lines and 0-types, NBNGS, 2011-2013

\begin{tabular}{|c|c|c|c|c|c|c|}
\hline \multirow{2}{*}{ CMS lines } & \multirow{2}{*}{$\begin{array}{l}\text { Effects of GCS } \\
\text { MS lines }\end{array}$} & \multicolumn{5}{|c|}{ Effects of SCA } \\
\hline & & Ot 1 & Ot 2 & Ot 3 & Ot 4 & Ot 5 \\
\hline CMS 1 & $-0.38^{*}$ & \# & -0.16 & $0.46^{*}$ & 0 & -0.31 \\
\hline CMS 2 & $0.24^{*}$ & 0.05 & \# & 0.04 & -0.09 & 0 \\
\hline CMS 3 & $0.27^{*}$ & 0.01 & $-0.39 *$ & $\#$ & 0.11 & 0.27 \\
\hline CMS 4 & -0.06 & -0.05 & 0.04 & -0.29 & \# & 0.30 \\
\hline CMS 5 & -0.07 & 0.15 & -0.15 & 0.25 & -0.26 & \# \\
\hline
\end{tabular}

${ }^{*} \mathrm{LSD}_{0.5}$

CMS 2 and CMS 3 lines were the carriers of additive genes in the environment of NBNGS. Significantly high effect of SCA was in the combination of CMS 1/Ot $3\left(+0.46^{*}\right)$, but hybrid combination with their participation did not show competitive heterosis (deviation from St was 3.3\%) because of the low effect of GCS of CMS lines $\left(-0.38^{*}\right)$ (Table 1).

Combination of CMS 2/Ot $5(17.6 \%)$ had a significant difference of sugar content from the average population values (Table 1), which is due to the additive effect of the mother parent form MS 2 $\left(+0.24^{*}\right)$ (Table 2).

Dispersion analysis of the data showed that effect of all components of the variation of genotypes was significant in the environment NBEGS. This allowed determining the proportion (Fig. 2), as well as the effects of combining abilities of parent lines of SSH (Table 3).

Table 3

The effects of GCA and SCA of the sugar content of CMS lines and 0-types, environment NBEGS

\begin{tabular}{c|c|c|c|c|cc|c}
\hline \multirow{2}{*}{ CMS lines } & Effects of GCS & \multicolumn{3}{|c}{ Effects of SCA } \\
\cline { 3 - 7 } & CMS lines & Ot 1 & Ot 2 & Ot 3 & Ot 4 & Ot 5 \\
\hline CMS 1 & $0.30^{*}$ & $\#$ & 0.13 & $-0.78^{*}$ & 0.13 & $0.52^{*}$ \\
CMS 2 & $-0.27^{*}$ & 0.09 & $\#$ & -0.31 & -0.34 & $0.55^{*}$ \\
CMS 3 & 0.08 & 0.34 & -0.23 & $\#$ & 0.01 & -0.13 \\
CMS 4 & -0.14 & 0.14 & 0.16 & $-0.40^{*}$ & $\#$ & 0.10 \\
CMS 5 & 0.03 & $-0.71^{*}$ & $1.15^{*}$ & $0.59^{*}$ & $-1.05^{*}$ & $\#$ \\
\hline
\end{tabular}

$* \operatorname{LSD}_{0.5}$

CMS 1 was the best among SCA in the environment of NBEGS, which was well combined with CMS Ot $5(\mathrm{SCA}=0.52 *)$. Their hybrids with showed the highest sugar content $(18.1 \%)$ (Table 1$)$. The components CMS 2/Ot 5, CMS 5/Ot 2 and CMS 5/Ot 3 had interaction effects that were significantly higher $(0.55,1.15$ and 0.59 , respectively), resulting in the increased level of sugar content in the hybrids $(17.5,17.7$ and $17.4 \%$, respectively).

Thus, non-additive variance was dominated by EGS compared with the NGS (60 vs. 30\%) against the normal fertilization background in the genotypic structure of variability of the sugar content characteristic.

EGS is the factor in which the effect of a genotype is higher than that of normal (86.6\% vs. 69.2\%), which indicates the feasibility of selecting the best genotypes in this environment. Differentiation ability of the environment NBEGS is higher than NBNGS (7 vs. 5 best hybrids were distinguished). The range of variation in sugar content in EGS was higher (2.2\%) compared to the NGS $(1.2 \%)$. Variability of GSA and SCA effects, as well as the specificity of the reaction of hybrids due to the change of GS was distinguished. The best hybrids in the environment NBEGS were hybrids CMS 3/0t 5 and CMS 2/Ot 5, and in the environment NBEGS CMS 1/Ot 5, CMS 3/Ot 1 and CMS 1/Ot 2.

\section{Sugar content of simple sterile hybrids in environments EBNGS and EBEGS}

Background of mineral supply influences the sugar content in a certain way, modifying its absolute value. The set of SSH was also tested on the enhanced background of mineral fertilization in two variations; with standard (EBNGS) and extended (EBEGS) growing space. Sugar content of hybrids is given in Table 4. 
Table 4

Sugar content of SSH, deviation from the average and standard in the environments EBNGS and EBEGS, IBCSB of NAAS, 2011-2013

\begin{tabular}{|c|c|c|c|c|c|c|}
\hline \multirow{3}{*}{$\begin{array}{l}\text { Simple sterile } \\
\text { hybrids }\end{array}$} & \multicolumn{6}{|c|}{ Area of supply } \\
\hline & \multicolumn{3}{|c|}{ EBNGS } & \multicolumn{3}{|c|}{ EBEGS } \\
\hline & $\begin{array}{c}\text { Sugar } \\
\text { content, \% }\end{array}$ & $\begin{array}{l}\text { Deviation } \\
\text { from the } \\
\text { average, } \%\end{array}$ & $\begin{array}{l}\text { Deviation } \\
\text { from St, \% }\end{array}$ & $\begin{array}{c}\text { Sugar } \\
\text { content, \% }\end{array}$ & $\begin{array}{l}\text { Deviation } \\
\text { from the } \\
\text { average, } \%\end{array}$ & $\begin{array}{l}\text { Deviation } \\
\text { from St, \% }\end{array}$ \\
\hline CMS $1 /$ Ot 2 & 17.7 & $-0.81^{*}$ & 3.1 & 18.2 & $1.16^{*}$ & 5.5 \\
\hline CMS 1/Ot 3 & 17.7 & $0.74^{*}$ & 2.7 & 17.1 & 0.09 & -0.7 \\
\hline CMS $1 /$ Ot 4 & 17.7 & $0.74^{*}$ & 2.7 & 16.8 & -0.17 & -2.3 \\
\hline CMS 1/Ot 5 & 17.2 & 0.31 & 0.2 & 17.5 & $0.46^{*}$ & 1.4 \\
\hline CMS 2/Ot 1 & 17.8 & $0.88^{*}$ & 3.5 & 17.4 & $0.43^{*}$ & 1.2 \\
\hline CMS 2/Ot 3 & 15.5 & $-1.42^{*}$ & -9.9 & 16.2 & $-0.84^{*}$ & -6.1 \\
\hline CMS 2/Ot 4 & 16.3 & $-0.62^{*}$ & -5.2 & 16.2 & $-0.80^{*}$ & -5.9 \\
\hline CMS 2/Ot 5 & 17.1 & 0.14 & -0.8 & 18.6 & $1.60 *$ & 8.0 \\
\hline CMS 3/Ot 1 & 16.5 & $-0.42^{*}$ & -4.1 & 17.8 & $0.83^{*}$ & 3.5 \\
\hline CMS 3/Ot 2 & 16.6 & -0.29 & -3.3 & 17.9 & $0.86^{*}$ & 3.7 \\
\hline CMS 3/Ot 4 & 16.6 & -0.32 & -3.5 & 15.3 & $-1.74^{*}$ & -11.4 \\
\hline CMS 3/Ot 5 & 17.6 & $0.64^{*}$ & 2.1 & 16.4 & $-0.60^{*}$ & -4.8 \\
\hline CMS 4/Ot 1 & 16.8 & -0.09 & -2.1 & 16.5 & $-0.47^{*}$ & -4.0 \\
\hline CMS 4/Ot 2 & 15.8 & $-1.09^{*}$ & -7.9 & 16.6 & $-0.44^{*}$ & -3.8 \\
\hline CMS 4/Ot 3 & 16.2 & $-0.69^{*}$ & -5.6 & 16.3 & $-0.74^{*}$ & -5.6 \\
\hline CMS 4/Ot 5 & 16.5 & $-0.42^{*}$ & -4.1 & 16.6 & $-0.40^{*}$ & -3.6 \\
\hline CMS 5/Ot 1 & 17.3 & $0.81^{*}$ & 3.1 & 18.1 & $1.10 *$ & 5.1 \\
\hline CMS 5/Ot 2 & 17.3 & 0.38 & 0.6 & 17.6 & $0.60 *$ & 2.2 \\
\hline CMS 5/Ot 3 & 16.7 & -0.22 & -2.9 & 16.2 & $-0.74^{*}$ & -5.6 \\
\hline CMS 5/Ot 4 & 16.8 & -0.12 & -2.3 & 16.6 & $-0.44^{*}$ & -3.8 \\
\hline
\end{tabular}

$* \operatorname{LSD}_{0.5}$

Analysis of Table 4 showed that against the background of EBNGS, five combinations were significantly higher than the average population value in terms of sugar content, while against the background of EBEGS eight combinations. The rate of reaction of the studied genotypes on EA was specific: some hybrids increased or lowered their sugar content, while other showed stability. However, the range of variation characteristics was different in two environments. The difference between the highest (CMS 1/Ot 2) and the lowest (CMS 3/Ot 4) values of sugar content was higher on EGS $(3.3 \%$, abs. index). It was smaller in the environment EBNGS $(2.0 \%$, hybrids CMS $2 / 0 t 1$ and CMS 4/Ot 2). In relation to the standard the significant excess was 2.1...3.5\% (EBNGS) and 2.2...8.0\% (EBEGS). The high sugar content on EA was observed in hybrids CMS 2/Ot 5 (18.6\%), CMS 5/Ot 1 (18.1\%) and CMS 1/Ot 2 (18.2\%). Combinations of CMS 2/Ot 1 (17.8\%), CMS 1/Ot 2, CMS 1/Ot 3 , CMS 1/Ot 4 (17.7\% each) were the best against the EBNGS.

Determination of the proportion in the total genotypic variability revealed that it is larger on EGS (92.4\%) compared to NGS (83.5\%). This indicates a better differentiating ability of EGS compared with CA.

Decomposition of genotypic variance (with the help of dispersion analysis) on the effects associated with different types of gene interactions showed that non-additive effects of genes on EGS had a larger proportion (50\%) compared to NGS $(40 \%)$ (Fig. 3, 4).

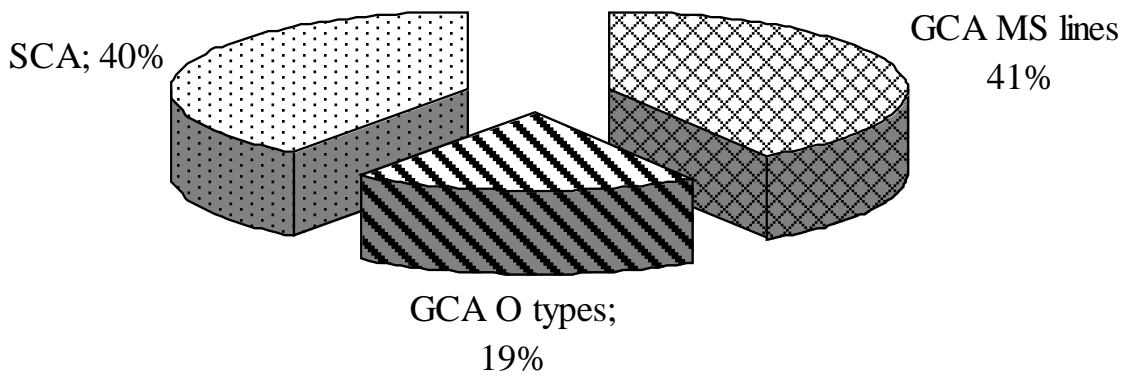

Fig. 3 Genotypic variability and its share in sugar content characteristic in simple sterile hybrids, 2011-2013, background EBNGS

ISSN 2410-1303 (online) Новіпні агротехнологї̈, 2015, № 1 


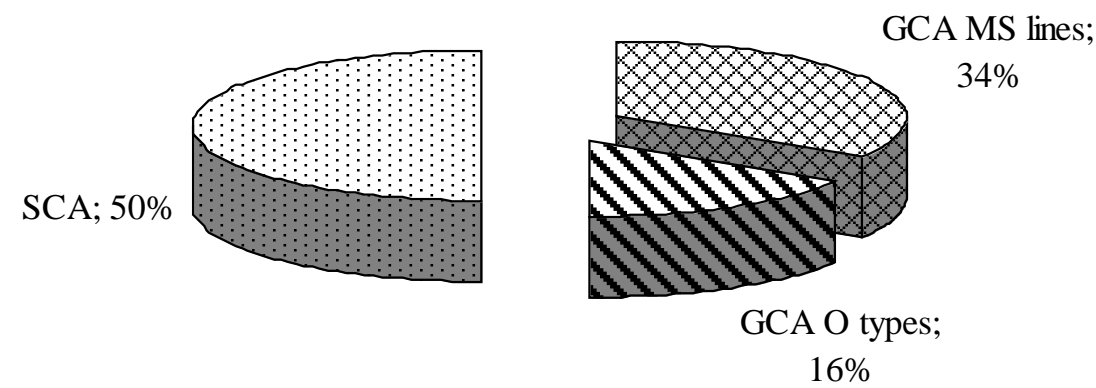

Fig. 4 Genotypic variability and its share of feature of sugar content of simple sterile hybrids, 2011-2013, background EBEGS

Analysis of Figures 3 and 4 showed that the effect of 0-types was approximately two times lower than that of CMS lines: 19 vs. $41 \%$ (EBNGS) and 16 vs. 34\% (EBEGS).

The significance of differences between SSH identified the effects of GCA and SCA components of hybridization and their expression depending on the growing space (Tables 5, 6). The variability of combining ability, depending on the environment was pointed out by many researchers. Thus, in some cases SCA was more stable, while in others GCA $[10,11]$.

Table 5

The effects of GCA and SCA on sugar content in CMS lines and 0-types, EBNGS

\begin{tabular}{c|c|c|c|c|c|c}
\hline \multirow{2}{*}{ CMS lines } & Effects of GCS & \multicolumn{5}{c}{ Effects of SCA } \\
\cline { 3 - 7 } & CMS lines & Ot 1 & Ot 2 & Ot 3 & Ot 4 & Ot 5 \\
\hline CMS 1 & $0.67^{*}$ & $\#$ & -0.25 & $0.41^{*}$ & 0.30 & $-0.47^{*}$ \\
CMS 2 & $-0.24^{*}$ & $0.72^{*}$ & $\#$ & $-0.84^{*}$ & -0.16 & 0.28 \\
CMS 3 & -0.09 & $-0.74^{*}$ & 0.13 & $\#$ & -0.01 & $0.62^{*}$ \\
CMS 4 & $-0.56^{*}$ & 0.07 & -0.19 & 0.09 & $\#$ & 0.03 \\
CMS 5 & $0.22^{*}$ & 0.19 & $0.49^{*}$ & -0.22 & $-0.46^{*}$ & $\#$ \\
\hline
\end{tabular}

$* \operatorname{LSD}_{0.5}$

As the data of table 5 showed, the best of SCA were CMS $1\left(+0.67^{*}\right)$ and CMS $5\left(+0.22^{*}\right)$. These lines possess a set of additive genes that will always influence the expression of the characteristic in $\mathrm{F}_{1}$. In specific combinations, in non-additive effects of genes are expressed very well, associating with dominance and overdominance, pairs of CMS 1 and Ot $3\left(0.41^{*}\right)$, CMS 2 , and Ot $1\left(0.72^{*}\right)$, CMS 3, and Ot $5\left(0.62^{*}\right)$, CMS 5 and Ot $2\left(0.49^{*}\right)$ showed themselves better. CMS 4 Line did not show itself in any combination, GCA was significantly lower $\left(-0.56^{*}\right)$, and all its hybrids exceeded standard by $2.1 \ldots 7.9 \%$ (Table 4).

CMS 1 line confirmed its high degree for GCA on EGS and NGS. GSA of this line was significantly higher $\left(+0.4^{*}\right)$, and CMC 5 line had a positive but not significant effect (0.14) (Table 6).

Table 6

Effects of GCA and SCA on sugar content of CMS lines and 0-types, EBEGS

\begin{tabular}{c|c|c|c|c|c|c}
\hline \multirow{2}{*}{ CMS lines } & Effects of GCS & \multicolumn{5}{c}{ Effects of SCA } \\
\cline { 3 - 7 } & CMS lines & Ot 1 & Ot 2 & Ot 3 & Ot 4 & Ot 5 \\
\hline CMS 1 & $0.67^{*}$ & $\#$ & -0.25 & $0.41^{*}$ & 0.30 & $-0.47^{*}$ \\
CMS 2 & $-0.24^{*}$ & $0.72^{*}$ & $\#$ & $-0.84^{*}$ & -0.16 & 0.28 \\
CMS 3 & -0.09 & $-0.74^{*}$ & 0.13 & $\#$ & -0.01 & $0.62^{*}$ \\
CMS 4 & $-0.56^{*}$ & 0.07 & -0.19 & 0.09 & $\#$ & 0.03 \\
CMS 5 & $0.22^{*}$ & 0.19 & $0.49^{*}$ & -0.22 & $-0.46^{*}$ & $\#$ \\
\hline
\end{tabular}

* $\operatorname{LSD}_{0.5}$

CMS 4 line was characterized by a negative and significant effect on SCA both on NGS and EGS $($ Tables 5,6$)$. Consequently, one can argue about the relative stability of GSA effects, which cannot be said about effects of SCA. Non-additive effects of genes of CMC 4 line with 0-types on EGS showed the contrast: with sterility maintainer Ot 1 they were significantly negative $\left(-0.58^{*}\right)$, while with 0 t 3 significantly positive $\left(+0.60^{*}\right)$, while on NGS they had no significant effect on the expression of sugar content in hybrid combinations with their participation. 
MS 3 line also had contrast: with Ot 1 and Ot 2 effects of SCA being positive $\left(0.37^{*}\right.$ and $\left.0.96^{*}\right)$, while with Ot 4 and Ot 5 negative $\left(-0.75^{*}\right.$ and $\left.0.58^{*}\right)$. On CA CMS 3 line with Ot 4 had a high positive effect of SCA. Consequently, the environment influenced the manifestation of non-additive effects of genes, and this effect is specific for each genotype.

Conclusion. Established was variability of phenotypic manifestation of sugar content against the different fertilization backgrounds and growing space. The best hybrids featured stable effect on the sugar content against both backgrounds were CMS 1/Ot 2, CMS 2/Ot 1, CMS 5/Ot 1 and CMS 2/0t 5, as evidenced by the cumulative effect of GCA and SCA. SCA was more variable in relation to the area of supply than GCA. CMC 1 and CMC 5 lines were distinguished as carriers of additive genes controlling sugar content and were characterized by stable phenotypic expression.

\section{Bibliography}

1. Савицкий В.Ф. Генетика сахарной свеклы / В.Ф. Савицкий // Свекловодство: Т. 1. - К.: Госсельхозиздат, 1940. - С. 561-580.

2. Корнеева М. А. Селекционно-генетическое изучение исходных популяций сахарной свеклы с целью создания комбинационно-ценных линий-опылителей : автореф. дис. на соискание ученой степени канд. биол. наук: спец. 03.00.15 «Генетика» / М. А. Корнеева; Институт молекулярной биологии и генетики. - К., 1987. - 20 с.

3. Балков И. Я. Гетерозис сахарной свеклы по признаку сахаристости / И. Я. Балков, В. П. Петренко, М. А. Корнеева // Вестник сельскохозяй ственной науки. - 1986. - № 10. - С. 55-59.

4. Логвинов В.А. Изменчивость содержания сахара в корнеплодах сахарной свеклы и отбор высокосахаристых растений / В.А. Логвинов, Л.Л. Чеботарь // Повышение эффективности производства сахарной свеклы на Северном Кавказе : сб. науч. тр. - Краснодар : [б. и.], 1985. - С. 48-53.

5. Роик Н.В. Комбинационная способность опылителей сахарной свеклы различной генетической структуры по элементам продуктивности / Н. В. Роик, М. А. Корнеева // Энциклопедия рода Beta: Биология, генетика и селекция свеклы / под ред. С. И. Малецкого. - Новосибирск : СовА, 2010. - С. 525541.

6. Корнєєва М. О. Успадкування цукристості топкросними ЧС гібридами цукрових буряків / М. О. Корнєєва, П. І. Вакуленко // Цукрові буряки. - 2006. - № 4. - С. 7-8.

7. Корнєєва М. О. Застосування адитивно-домінантної моделі для оцінки ліній цукрових буряків / М. 0. Корнєєва, Е. Р. Ермантраут, М. В. Власюк // Наукові праці Інституту цукрових буряків : зб. наук. пр. К. : ПоліграфКонсалтинг, 2007. - Вип. 9. - С. 164-171.

8. Мазлумов А. Л. Селекция сахарной свеклы / А. Л. Мазлумов. - М. : Колос, 1970. - 206 с.

9. Балков И. Я. Закономерности наследования сахаристости и принципы отбора высокосахаристых форм в селекции сахарной свеклы / И. Я. Балков, В.Г. Перетятько // Основы повышения сахаристости и технологических качеств сахарной свеклы : сб. науч. тр. - К. : ВНИС, 1986. - С. 70-77.

10. Бережко С. Т. Комбинационная способность у тетраплоидной сахарной свеклы и условия внешней среды / С. Т. Бережко // Генетические исследования сахарной свеклы. - К. : ВНИС, 1975. - С. 75-86.

11. Петренко В.П. Использование комбинационной способности в селекционном процессе / В.П. Петренко // Генетические исследования сахарной свеклы. - К. : ВНИС, 1975. - С. 86-96.

\section{References}

1. Savitskiy, V. F. (1940). Genetics of sugar beets. In Sveklovodstvo [Sugar beet production] (Vol. 1, pp. 561-580). Kiev: N.p. [in Russian]

2. Korneeva, M. A. (1987). Selektsionno-geneticheskoe izuchenie iskhodnykh populyatsiy sakharnoy svekly s tsel'yu sozdaniya kombinatsionno-tsennykh liniy-opyliteley [Selection and genetic study of initial populations of sugar beet in order to create value-combined lines-pollinators]. (Extended abstract of Cand. Biol. Sci. Diss.). Kiev, Institute of Molecular Biology and Genetics. [in Russian]

3. Balkov, I. Ya., Petrenko, V. P., \& Korneeva, M. A. (1986). Heterosis of sugar beet as to its sugar content. Vestnik sel'skokhozyaystvennoy nauki [The Bulletin of Agricultural Science], 10, 55-59. [in Russian]

4. Logvinov, V. A., \& Chebotar, L. L. (1985). Variability of sugar content in the roots of sugar beet plants and selection of plants with high sugar content. In Povyshenie effektivnosti proizvodstva sakharnoy svekly na Severnom Kavkaze [Increase of the efficiency of sugar beet production in the North Caucasus] (pp. 48-53). Krasnodar: N.p. [in Russian] 
5. Roik, N. V., \& Korneeva, M. A. (2010). Combining ability of sugar beet pollinators of different genetic structure as to the elements of productivity. In S. I. Maletskiy (Ed.) Entsiklopediya roda Beta: Biologiya, genetika $i$ selektsiya svekly [Encyclopedia of the genus Beta: Biology, genetics and selection of beets] (pp. 525-541). Novosibirsk: SovA. [in Russian]

6. Kornieieva, M. O., \& Vakulenko, P. I. (2006). Inheritance of sugar content by top-crossed MS hybrids of sugar beet. Tsukrovi buriaky [Sugar beet], 4, 7-8. [in Ukrainian]

7. Kornieieva, M. O., Ermantraut, E. R., \& Vlasiuk, M. V. (2007). The use of additive-dominant model for the evaluation of lines of sugar beet. Naukovi pratsi Instytutu tsukrovykh buriakiv [Scientific papers of the Institute of Sugar Beet], 9, 164-171. [in Ukrainian]

8. Mazlumov, A. L. (1970). Selektsiya sakharnoy svekly [Sugar beet breeding]. Moscow: Kolos. [in Russian]

9. Balkov, I. Ya., \& Peretyat'ko, V. G. (1986). Patterns of inheritance of sugar content and guidelines for the selection of forms with high sugar content in the selection of sugar beet. In Osnovy povysheniya sakharistosti $i$ tekhnologicheskikh kachestv sakharnoy svekly [Basics of increasing of sugar content and technological properties of sugar beet] (pp. 70-77). Kiev: VNIS. [in Russian]

10. Berezhko, S. T. (1975). Combining ability in tetraploid sugar beet and environmental conditions. In Geneticheskie issledovaniya sakharnoy svekly [Genetic studies of sugar beet] (pp. 75-86). Kiev: VNIS. [in Russian]

11. Petrenko, V.P. (1975). The use of combining ability in the selection process. In Geneticheskie issledovaniya sakharnoy svekly [Genetic studies of sugar beet] (pp. 86-96). Kiev: VNIS. [in Russian]

\section{Анотація}

УДК 633.63:631.52

Корнєєва М. О., Ненька М. М. Мінливість цукристості простих стерильних гібридів як материнських компонентів експериментальних комбінацій залежно від генотипу і контрольованих факторів середовища

Інститут біоенергетичних культур і цукрових буряків НААН України, вул. Клінічна, 25, м. Київ, 03141, *e-mail: mira31@ukr.net

Мета. Визначити генетичну детермінованість і фенотиповий прояв простих стерильних гібридів як материнських компонентів експериментальних комбінацій залежно від різних фонів удобрення і площ живлення та відібрати кращі з них за адаптивною здатністю до абіотичних факторів середовища. Методи. Сортовипробовування простих стерильних гібридів, а також закріплювачів стерильності та їх ЧС аналогів у різних середовищах: звичайний фон удобрення - звичайна площа живлення (ЗФЗП), звичайний фон - розширена площа живлення (ЗФРП), підвищений фон удобрення - звичайна площа (ПФЗП) і підвищений фон - розширена площа живлення (ПФРП). Результати. На звичайному фоні удобрення у генотиповій структурі мінливості ознаки цукристість неадитивна варіанса зростала на РП. Диференціювальна здатність середовища ЗФРП вища, ніж ЗФЗП (виділено сім кращих гібридів проти п’яти). На підвищеному фоні удобрення розширена площа також була кращим середовищем для добору генетично цінних за цукристістю ліній. У середовищі ПФРП виявлено 8 гібридів, що істотно перевищують середньопопуляційне значення, проти 5 на ПФЗП. Частка неадитивна дії генів на РП була також більшою порівняно із ЗП - 50 проти 40 \%. Висновки. Встановлена мінливість фенотипового прояву цукристості залежно від різних фонів мінерального удобрення і площ живлення. Кращими гібридами, що мали стабільний прояв високої цукристості на обох фонах, були ЧС 1 /От 2, ЧС 2/От 1 , ЧС 5/От 1 та ЧС 2/От 5, що підтверджено сумарними ефектами ЗКЗ і СКЗ. СКЗ була більш мінливою щодо площі живлення ніж ЗКЗ. Виділено лінії ЧС 1 і ЧС 5 як носії цінних адитивних ефектів генів із стабільним проявом.

Ключевые слова: ЧС (пилкостерильні) лінії, закріплювачі стерильності, прості стерильні гібриди, иукристість, комбінаційна здатність.

\section{Аннотация}

УдК 633.63:631.52

Корнеева М. А., Ненька М.Н. Изменчивость сахаристости простых стерильных гибридов как материнских компонентов экспериментальных комбинаций в зависимости от генотипа и контролируемых факторов среды

Институт биоэнергетических культур и сахарной свеклы НААН Украины, ул. Клиническая, 25, г. Киев, 03141, *e-mail:mira31@ukr.net

1SSN 2410-1303 (online) Novitni agrotehnologï̈ [Advanced Agrotechnologies], 2015, No. 1 
Цель. Определить в многофакторном эксперименте генетическую детерминацию и фенотипическое проявление сахаристости простых стерильных гибридов как материнских компонентов экспериментальных комбинаций в зависимости от различных фонов удобрения и площадей питания и отобрать лучшие из них по адаптивной способности к абиотическим факторам среды. Методы. Сортоиспытание простых стерильных гибридов, а также закрепителей стерильности и их МС аналогов в различных средах: обычный фон удобрения - обычная площадь питания (ОФОП), обычный фон расширенная площадь питания (ОФРП), повышенный фон удобрения - обычная площадь (ПФоП) и повышенный фон - расширенная площадь питания (ПФРП). Результаты. На обычном фоне удобрения в генотипической структуре изменчивости признака сахаристость неаддитивная варианса возрастала на РП. Дифференцирующая способность среды ОФРП выше, чем ОФОП (выделено 7 лучших гибридов против 5). На повышенном фоне удобрения расширенная площадь также была лучшей средой для отбора генетически ценных по сахаристости линий. В среде ПФРП выявлено 8 гибридов, существенно превышающих среднепопуляционное значение, против 5 на ПФОП. Доля неаддитивного действия генов на РП была также выше по сравнению с ОП - 50 против 40 \%. Выводы. Установлена изменчивость фенотипического проявления сахаристости в зависимости от различных фонов минерального удобрения и площадей питания. Лучшими гибридами, имеющими стабильное проявление высокой сахаристости на обоих фонах, были MC 1/От 2, MC 2/0т 1, МС 5/От 1 и МС 2/От 5, что подтверждается суммарными эффектами ОКС и СКС. СКС была более изменчивой относительно площади питания, чем ОКС. Выделены линии МС 1 и MC 5 как носители ценных аддитивных эффектов генов, контролирующих сахаристость, со стабильным фенотипическим проявлением.

Ключевые слова: МС (пыльцестерильные) линии, закрепители стерильности, простые стерильные гибриды, сахаристость, комбинационная способность. 